\title{
FISCAL POLICY IN BOSNIA AND HERZEGOVINA - AN INSTRUMENT FOR FASTER GROWTH OR ECONOMIC STAGNATION?
}

\author{
Faruk Hadžić \\ University of Sarajevo, School of Science and Technology - Sarajevo \\ faruk.hadzic@ssst.edu.ba \\ Nebojša Savanović \\ University of Banja Luka, Economic faculty - \\ nebojsasavanovic87@gmail.com
}

\begin{abstract}
The paper investigates the impact of fiscal policy on economic growth, foreign direct investment and employment in Bosnia and Herzegovina. The focus of research is fiscal policy, which as a lever of economic policy that affects economic growth and development. The aim of the research is to determine the impact of fiscal policy on the economy of Bosnia and Herzegovina and propose solutions for higher growth and development, a higher degree of foreign direct investment and reducing the unemployment rate. The results of the research show that the fiscal policy for the years that are the subject of the research, has affected the public debt of the state. High taxes and contributions have contributed to the spread of the gray economy, fiscal discipline is at a low level due to the management in this way of this lever of economic policy. Public financial management should be one of the key macroeconomic goals, with special emphasis on fiscal policy. The research went in the direction of analyzing current trends and proposals for improving the situation. The research aims to show the current statistical impact of variables on gross domestic product, on growth and development and the impact after the application of expansionary fiscal policy on the same variables. It is recommended that economic policy be conducted in the direction of releasing additional funds through the redistribution of taxes in favor of workers, in the direction of capital investments that will repay themselves, to reduce the rate of taxes and contributions on wages and with incentives for investors, to go towards stimulating production and tax reliefs for export-oriented activities with an effort to try to produce products whose production is possible in our conditions, and all this is mostly possible with the implementation of an expansive fiscal policy.
\end{abstract}

Keywords: Macroeconomics, Fiscal Policy, GDP, Public Expenditure, Investments

JEL classification: E62, O23

\section{INTRODUCTION}

If we analyze countries around the world, it can be noticed that each country conducts its fiscal policy differently, and it is therefore difficult to find two countries that have identical fiscal policies. Some economies, such as the United States, operate on a more significant use of direct taxes as part of fiscal policy (Turnovsky et al., 1987) in contrast to the EU, where the ratio of indirect taxes to the functioning of fiscal policy is more significant (Wildasin, 2000).

Bosnia and Herzegovina, like the EU, has a high importance of indirect taxes in conducting fiscal policy. Competence in the field of fiscal policy in $\mathrm{BiH}$ is divided between the state level and the entities. Until 2005, the competence in the areas of taxes was at the level of the entities, and with the reform of the tax system, ie the introduction of VAT, the competence was transferred to the level of the state. VAT revenues are collected in a single state account at a flat rate of $17 \%$, from where they are distributed to the entities according to the agreed 
coefficient. Jurisdiction in the field of direct taxes is legally regulated at the entity level. Income tax is $10 \%$ in both entities (Hadzic et al., 2010), as well as corporate income tax, while contribution rates vary between entities in Bosnia and Herzegovina. The division in the competences of fiscal policy leads to the entities pursuing different economic policies, which have different effects at the level of the economy.

The balanced budget policy in Bosnia and Herzegovina represents the distribution of collected current tax revenues on expenditures without significant investment in productive purposes that can lead to higher long-term rates of economic growth. On the other hand, the lack of investment as a consequence of a balanced budget has led to limited economic progress accompanied by a reduction in the active labor force and a growing emigration of people from Bosnia and Herzegovina.

In this paper, we explore the relationship between government expenditure and GDP through a created model of linear regression, to show that a balanced budget policy has led to limited economic growth in Bosnia and Herzegovina. In addition, through a simulation based on our model, we want to show that through higher government expenditures, which would be based on fiscal expansion, there can be a significant increase in GDP, and thus faster economic progress of Bosnia and Herzegovina.

\section{LITERATURE REVIEW}

Robert J. Barro, the Paul M. Warburg Professor of Economics at Harvard University, conducted a profound empirical study of growth factors both in the countries with advanced economies, as well as in the countries with moderate per capita income. He discovered that the excessive state influence on the national economy slowed down the growth of real GDP (Barro, 1996).

Agell et al. (1997) did not make a unified conclusion about the impact (either positive or negative) of the share of GDP redistribution through the budget system.

Swedish researchers Fölster and Henrikson (1999) determined that a substantial share of GDP redistribution through the budget system and public finances had rather strong negative effect on economic development in advanced market economies. At the same time, there are some scientific studies showing that in terms of economic instability the public institutions (responsible for the fiscal policy) play a key role to secure the restoration of positive macroeconomic dynamics through additional public spending or redistribution of the budget expenditures.

DeLong and Summers (2012) emphasized the vital role of fiscal policy aimed to restore positive economic dynamics. Cogan et al. (2013) identified the measures of fiscal policy ensuring economic growth both in the short and long run.

Paparas et al. (2014) investigated the relationship between fiscal policy and economic growth in the EU-15, with an attempt to determine which of the fiscal policy instruments enhance economic growth. They have deployed panel data techniques and included both sides of budget, spending and taxation. They have concluded that gross fixed capital formation of the private sector as a percentage of GDP has no significant impact on economic growth.

Pasichnyi (2017) examined the role of fiscal policy in the economic growth ensuring in advanced and emerging market economies over the period from 2001 to 2015 . The research indicates the growing role of the state and the budget in regulation of social and economic processes.

Hanush et al. (2017) analyzed the effectiveness of public expenditures on economic growth within the analytical framework of comprehensive Neo-Schumpeterian economics. Their results revealed that the impact of innovation-related spending on economic growth is much higher than that of the other macro variables. 
Shaw (2016) extended a model of fiscal policy volatility and output growth by including more general institutional processes. The results provided empirical support to the notion that fiscal policy stability generates higher long-run growth.

Hodžić et al. (2020) explored the relationship and effects of fiscal policy and economic growth in 21 Central and Eastern European (CEE) countries over the period 2000-2018. The results, implied that an increase in taxation, but not in non-productive expenditures, can positively affect economic growth.

Golemi and Muco (2020) examined the impact of fiscal policy on economic growth in the eight western Balkan countries for the period 2005-2018. The results suggest that fiscal revenues have a positive impact on the economic growth of the countries under consideration. The empirical results also suggest that tax increases have a relatively low negative impact on the flow of foreign direct investments in these countries.

Karalić and Kumalić (2019) investigated in its paper fiscal policy measures that need to determine the level of tax burden that will stimulate investments primarily private sector economy. They have concluded that the balance between indirect and direct taxes should be seen in the sensitivity to the regressive effects of the value added tax and include a broad base of taxation on income and income tax.

Bošnjak and Zlatković (2015) analized the effects of public expenditure reduction on economic growth in B\&H, where they used the VAR model with monthly data of the following variables: GDP, Unemployment, Real Wages, Exports, Imports and Public Expenditure. Their results showed that the TFP shock will not have permanent effects, while the Public Expenditure shock will have more persistent effects on the observed variables.

Taking into account all the previous studies, the continuation of scientifc research had to determine the importance and impact of budgetary and tax instruments ensuring the social and economic development is essential.

\section{METHODOLOGICAL FRAMEWORK}

As part of the research, we set a hypothesis:

H0: Fiscal policy of balanced budget did not lead to significant economic growth, employment growth and inflow of foreign direct investment in BiH in the period 2014-2019.

For the purposes of the research, secondary data were collected for the analysis of the movement of the gross domestic product of $\mathrm{BiH}$, in the period $2000-2019$, according to the expenditure approach. In addition, data on the movement of total government expenditures for the same period were collected. The time series covers 85 quarterly values of GDP and government expenditure at current prices. In order to create an economic model, a regression model was prepared between the independent variable "Government expenditure" and the dependent variable "GDP". The regression model should show a direct link between these variables in order to prove that the current conduct of government fiscal policy has not had a significant effect on economic growth.

In order to compare GDP trends in the period 2014-2019 for Bosnia and Herzegovina, and to compare with neighboring countries, secondary World Bank data on GDP trends per capita were collected to establish a direct link between government expenditures and GDP, and finally between GDP per capita movements between countries.

Data from the Agency for Statistics of Bosnia and Herzegovina, related to labor force movements, according to the Labor Force Survey, were used to show labor force movements in the period.

The measurement of the level of foreign direct investment is shown through the collected secondary data of the World Bank.

Finally, population emigration trends are shown through Eurostat secondary data collected. 


\section{DISCUSSION AND RESULTS}

In order to prove the hypothesis, a regression model was created between the independent variable Government expenditures and the dependent variable GDP based on 85 quarterly values of GDP values and government expenditures at current prices. Based on the data shown in Table 1., it can be seen that there is a very strong relationship between the observed variables, which is confirmed by R Square which is 0.95 . Additionally, the value of $p<0.05$ for the value of the variable and the coefficient, which indicates that the obtained results are statistically significant.

SUMMARY OUTPUT

Table 1. - Research results - Regression output

\begin{tabular}{lr}
\hline \multicolumn{2}{c}{ Regression Statistics } \\
\hline Multiple R & 0,97513528 \\
R Square & 0,9508888 \\
Adjusted R Sq & 0,9502971 \\
Standard Erro & 402445,117 \\
Observations & 85 \\
\hline
\end{tabular}

ANOVA

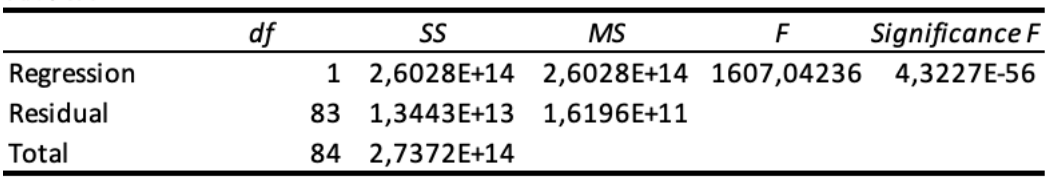

\begin{tabular}{lcccccccc}
\hline & Coefficients & itandard Error & t Stat & \multicolumn{1}{c}{ P-value } & \multicolumn{1}{c}{ Lower 95\% } & Upper 95\% & Lower 95,0\% & Upper 95,0\% \\
\hline Intercept & $-179928,82$ & 170681,173 & $-1,0541808$ & 0,29485924 & $-519406,81$ & 159549,165 & $-519406,81$ & 159549,165 \\
X Variable 1 & 5,02174187 & 0,12526817 & 40,0879328 & $4,3227 \mathrm{E}-56$ & 4,77258853 & 5,27089522 & 4,77258853 & 5,27089522 \\
\hline
\end{tabular}

(Source: Calculation of authors based on data from the Agency for Statistics of BiH)

Based on this research results of regression model we have established formula to predict value of GDP for given Government expenditure:

$$
\text { GDP = -179928,823745701 + 5,02174187242985 x „Government Expenditure“ }
$$

The link between these two variables is very important because it proves that government expenditures have a significant impact on GDP growth in Bosnia and Herzegovina. In order to further confirm this thesis, we analyzed the annual amounts of government expenditure and GDP in the period 2001-2020. According to these data, which are shown in Table XX, two periods can be observed, the first period from 2001 - 2008, when the expansionary fiscal policy in Bosnia and Herzegovina was pursued, and the period after the arrival of the Great Depression from 2009-2020, when the policy of a balanced budget was pursued while maintaining a certain level of government expenditure, and thus slow GDP growth. In the first period from 2001 to 2008 , government expenditures increased by $75.5 \%$, while GDP increased by $81.5 \%$ in the same period. In the second observed period from 2009 to 2020, which is four years longer than the first period, the growth of Government Expenditures amounted to 20.9\%, while GDP grew by $32.7 \%$. In other words, over a period of 12 years, Bosnia and Herzegovina has managed to increase its GDP by less than $1 / 3$.

Table 2. - The annual amounts of government expenditure and GDP of BiH 


\begin{tabular}{|c|c|c|}
\hline Categories $\rightarrow$ & $\begin{array}{l}\text { Of general } \\
\text { Government }\end{array}$ & $\begin{array}{l}\text { Gross } \\
\text { domestic }\end{array}$ \\
\hline \multirow[b]{2}{*}{ Time $\downarrow$} & & \\
\hline & \multicolumn{2}{|l|}{ Total } \\
\hline 2001 & 2.793 .251 & 13.893 .017 \\
\hline 2002 & 2.983 .010 & 15.084 .499 \\
\hline 2003 & 3.438 .828 & 16.297 .360 \\
\hline 2004 & 3.356 .602 & 17.137 .937 \\
\hline 2005 & 3.560 .422 & 18.141 .976 \\
\hline 2006 & 3.937 .011 & 20.499 .951 \\
\hline 2007 & 4.360 .316 & 23.059 .336 \\
\hline 2008 & 4.902 .967 & 25.219.074 \\
\hline 2009 & 5.698 .487 & 26.256 .823 \\
\hline 2010 & 5.915 .571 & 26.505 .970 \\
\hline 2011 & 5.813 .472 & 27.133 .810 \\
\hline 2012 & 6.130 .722 & 27.471 .859 \\
\hline 2013 & 6.114 .443 & 28.604 .041 \\
\hline 2014 & 6.203 .694 & 29.039 .716 \\
\hline 2015 & 6.258 .447 & 30.105 .850 \\
\hline 2016 & 6.290 .377 & 31.387 .644 \\
\hline 2017 & 6.358 .870 & 32.733 .878 \\
\hline 2018 & 6.426 .110 & 34.183 .465 \\
\hline 2019 & 6.669 .225 & 35.862 .083 \\
\hline 2020* & 6.888 .611 & 34.843 .099 \\
\hline
\end{tabular}

World Bank data show that in the period 2014-2019, according to the GDP per capita indicator, there was a slowdown in growth for Bosnia and Herzegovina, and in relation to neighboring countries there was a further increase in the difference. According to the data from Table 3, it can be seen that the GDP of the pc for Bosnia and Herzegovina increased by $\$ 744$, for Croatia $\$ 1,253$ for Serbia $\$ 802$, and for Montenegro $\$ 1,444$. By converting these data and comparing them with Croatia, which has the highest amount of GDP per capita in the region, it can be seen that Bosnia and Herzegovina is at the level of $40.89 \%$ of the Croatian level. The details are shown graphically in Table 3.

Table 3. - GDP per capita of BiH in relation to neighboring countries 


\begin{tabular}{|l|c|c|c|c|c|r|r|r|}
\hline IN MILLIONS CURRENT \$ & $\mathbf{2 0 1 4}$ & $\mathbf{2 0 1 5}$ & $\mathbf{2 0 1 6}$ & $\mathbf{2 0 1 7}$ & $\mathbf{2 0 1 8}$ & $\mathbf{2 0 1 9}$ & INCREASE & $\%$ 2018/2015 \\
\hline GDP B\&H & 18.558 & 16.212 & 16.913 & 18.080 & 20.183 & 20.048 & 1.490 & $7,43 \%$ \\
\hline GDP CROATIA & 57.643 & 49.531 & 51.597 & 55.320 & 60.991 & 60.416 & 2.773 & $4,59 \%$ \\
\hline GDP SERBIA & 47.062 & 39.629 & 40.630 & 44.120 & 50.597 & 51.409 & 4.347 & $8,46 \%$ \\
\hline GDP MONTENEGRO & 4.594 & 4.053 & 4.374 & 4.845 & 5.507 & 5.495 & 901 & $16,40 \%$ \\
\hline IN CURRENT \$ & $\mathbf{2 0 1 4}$ & $\mathbf{2 0 1 5}$ & $\mathbf{2 0 1 6}$ & $\mathbf{2 0 1 7}$ & $\mathbf{2 0 1 8}$ & $\mathbf{2 0 1 9}$ & INCREASE & $\% \mathbf{2 0 1 8 / 2 0 1 5}$ \\
\hline GDP B\&H PC & 5.329 & 4.727 & 4.994 & 5.394 & 6.072 & 6.073 & 744 & $12,14 \%$ \\
\hline GDP CROATIA PC & 13.600 & 11.782 & 12.360 & 13.412 & 14.920 & 14.853 & 1.253 & $8,82 \%$ \\
\hline GDP SERBIA PC & 6.600 & 5.585 & 5.756 & 6.284 & 7.246 & 7.402 & 802 & $8,92 \%$ \\
\hline GDP MONTENEGRO PC & 7.388 & 6.514 & 7.028 & 7.784 & 8.850 & 8.832 & 1.444 & $16,59 \%$ \\
\hline IN CURRENT \$ & $\mathbf{2 0 1 4}$ & $\mathbf{2 0 1 5}$ & $\mathbf{2 0 1 6}$ & $\mathbf{2 0 1 7}$ & $\mathbf{2 0 1 8}$ & $\mathbf{2 0 1 9}$ & INCREASE \\
\hline GDP B\&H PC & $39,18 \%$ & $40,12 \%$ & $40,40 \%$ & $40,22 \%$ & $40,70 \%$ & $40,89 \%$ & $1,70 \%$ \\
\hline GDP CROATIA PC & $100,00 \%$ & $100,00 \%$ & $100,00 \%$ & $100,00 \%$ & $100,00 \%$ & $100,00 \%$ & $0,00 \%$ \\
\hline GDP SERBIA PC & $48,53 \%$ & $47,40 \%$ & $46,57 \%$ & $46,85 \%$ & $48,57 \%$ & $49,84 \%$ & $1,31 \%$ \\
\hline GDP MONTENEGRO PC & $54,32 \%$ & $55,29 \%$ & $56,86 \%$ & $58,04 \%$ & $59,32 \%$ & $59,46 \%$ & $5,14 \%$ \\
\hline
\end{tabular}

(Source: Author's creation based on World Bank Data)

Graph 1. - The number of employed workers in BiH and neighboring countries

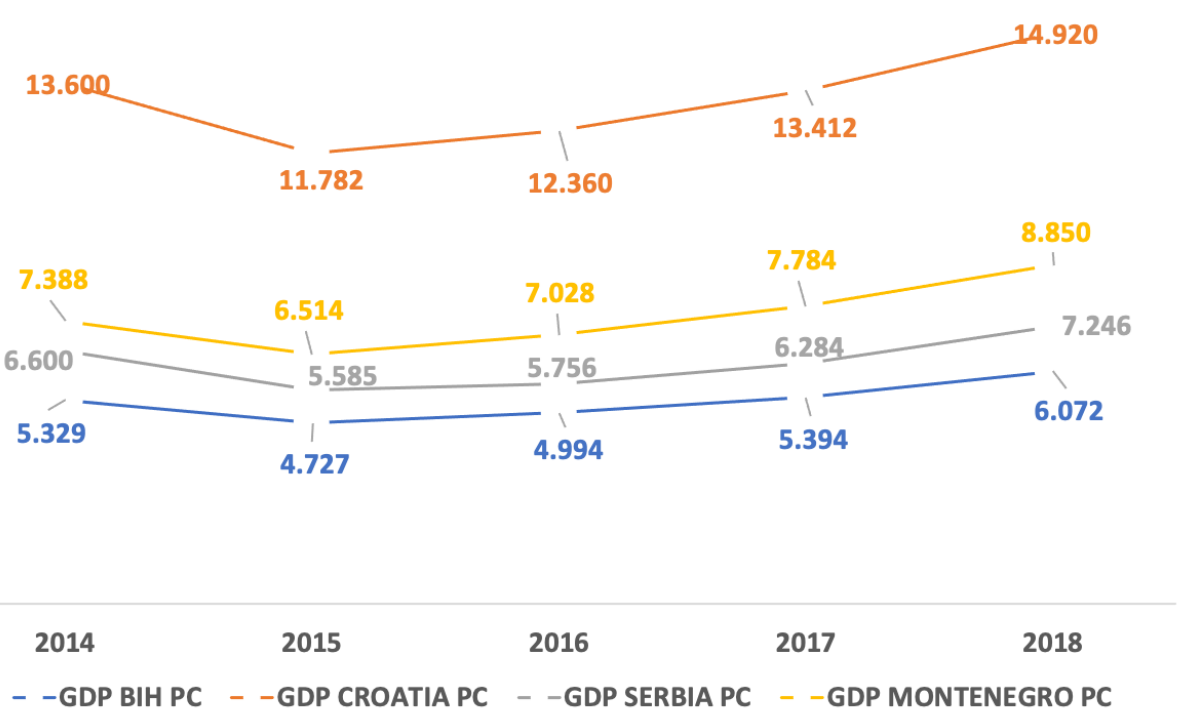

(Source: Juric et al, 2021)

If we observe the trends in the number of employed workers in Bosnia and Herzegovina during the period 2014-2018, according to the data from the BiH Labor Force Survey, it can be seen that in the past period there was an increase in the number of employed workers by 10,000 , but also a decrease in the number of unemployed workers. by 123,000 workers, which ultimately led to a reduction in the total workforce by 113,000. Considering that in the observed period of conducting a balanced budget policy, there was no significant increase in employed workers, and that the total labor force decreased, there was a slowdown in economic growth in Bosnia and Herzegovina. Details on the movement of the number of workers are shown in Graph 2.

Graph 2. - The number of unemployed workers, the labor force in BiH 


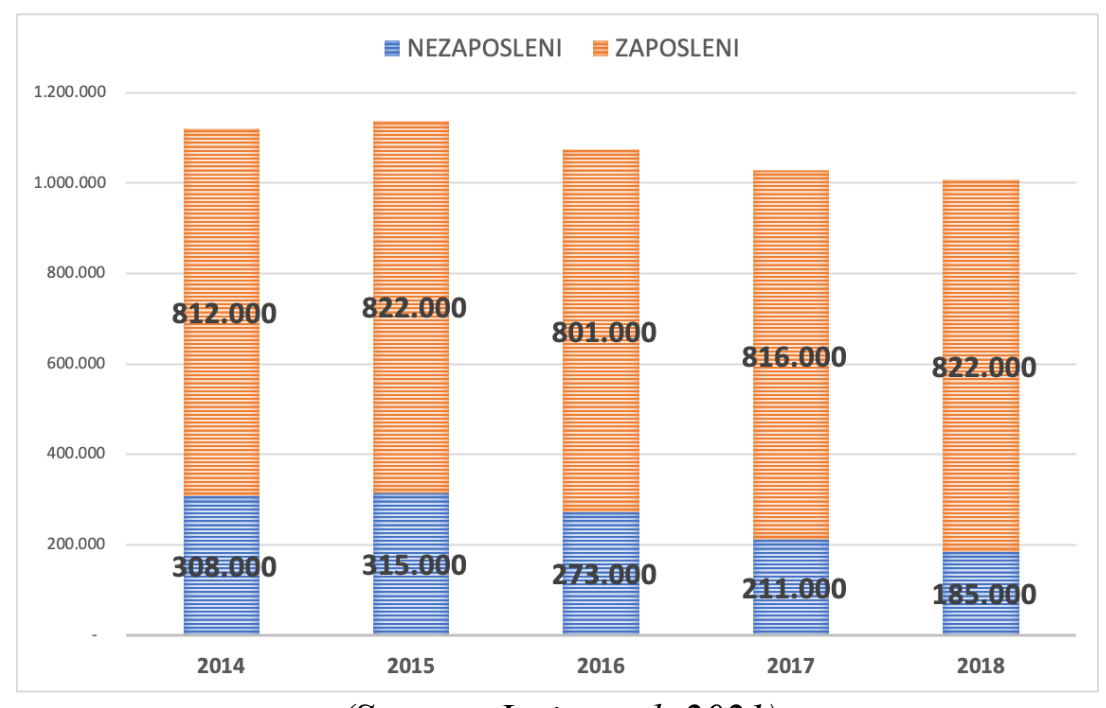

(Source: Juric et al, 2021)

The stated number of reductions in the number of unemployed workers, as well as the labor force in $\mathrm{BiH}$, could mean that the mentioned persons left Bosnia and Herzegovina and moved to the countries of the European Union. Eurostat data (EUROSTAT, 2019a) relating to all valid permits by reason, length of validity, and citizenship on 31. December of each year, show that in the period 2014 -2019 the total number of citizens of Bosnia and Herzegovina increased, which had a permanent permit by any reason in EU countries. According to these data for the observed period, the number of citizens increased by 108,251 (Juric et al., 2021), which is shown in Figure 3.

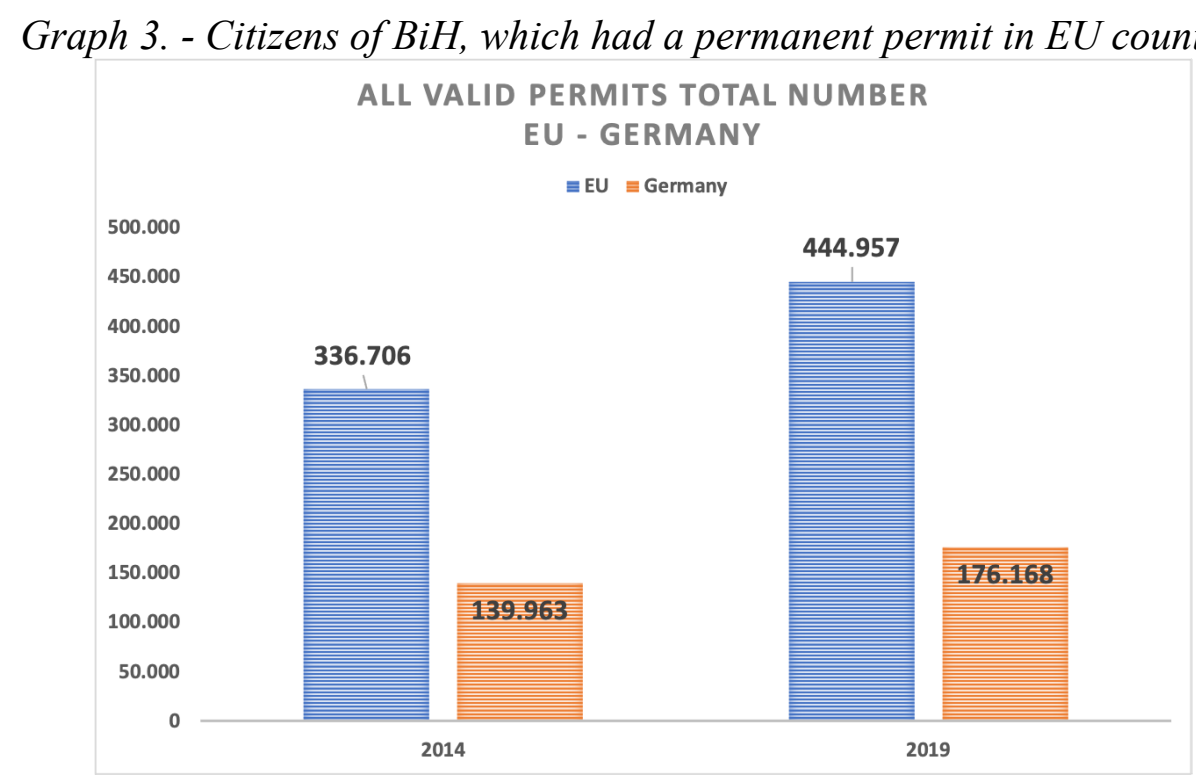

(Source: Juric et al., 2021)

The final indicator that the fiscal policy of a balanced budget has led to a reduced inflow of FDI is also shown graphically in Graph 4. According to the World Bank, BiH had a significant increase in FDI inflows in the period 2001-2008, when an expansive fiscal policy was pursued, and in the period 2009-2019 there was a reduced and limited amount of FDI arrivals in Bosnia and Herzegovina. 


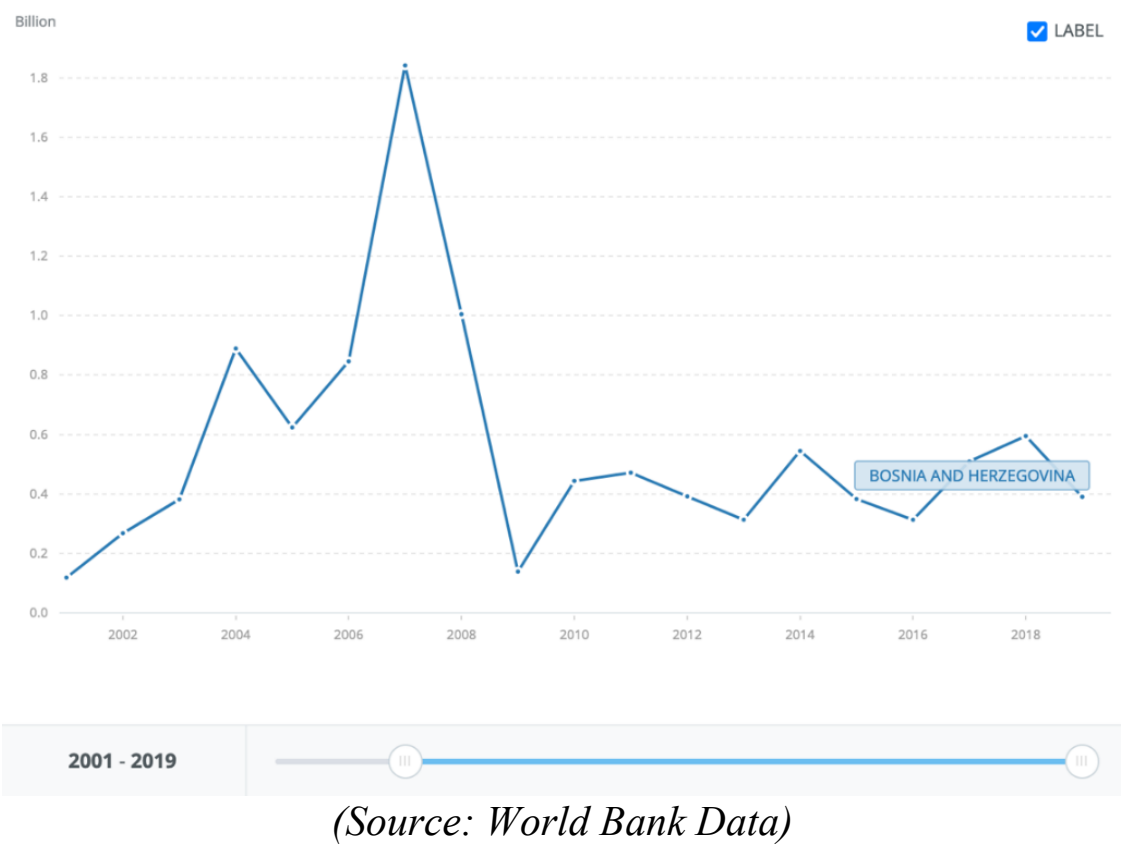

In order to increase the level of economic activity through the conduct of expansionary fiscal policy in the coming years, based on our proposed regression model, we offered a simulation of GDP growth, in case of annual increase in government expenditures, which can occur by reducing the tax burden on labor, where most of the reduction would be aimed at increasing lower wages, which, along with the growth of household consumption, would lead to more taxes collected in the coming years. Based on the assumptions of our model and the assumption that in this way government expenditures would grow by $10 \%$ per year, it can be seen from Table 4, that there would be a significant increase in GDP in $\mathrm{BiH}$ in the amount of $31.9 \%$. In this case, there would be an increase in BiH's GDP in just four years to the same extent as the increase in the last 12 years through a balanced budget policy.

Table 4. - Simulation of GDP growth

\begin{tabular}{|c|c|l|}
\hline \multirow{2}{*}{ Categories $\rightarrow$} & $\begin{array}{l}\text { Of general } \\
\text { Government }\end{array}$ & $\begin{array}{l}\text { Gross } \\
\text { domestic } \\
\text { product }\end{array}$ \\
\cline { 1 - 2 }$\downarrow$ & Total & \\
\hline $\mathbf{2 0 2 1}$ & 7.577 .472 & 37.872 .179 \\
\cline { 1 - 1 } $\mathbf{2 0 2 2}$ & 7.956 .345 & 39.774 .784 \\
\cline { 1 - 1 } $\mathbf{2 0 2 3}$ & 8.354 .163 & 41.772 .520 \\
\cline { 1 - 1 } $\mathbf{2 0 2 4}$ & 9.189 .579 & 45.967 .765 \\
\hline
\end{tabular}

(Source: Author's own calculations based on BiH Agency for Statistics)

The growth of tax revenues can be achieved in several ways. Currently, high contribution rates for pension and health insurance are a major problem, with a significant number of employers hiring undeclared workers ${ }^{1}$. It is necessary to make a reform in this segment, where the obligations for pension and health insurance will be further reduced, which would introduce employers who work in the gray zone and who employ illegal workers in the system, and start the process of paying contributions. The initial loss, which would be realized by reducing the

\footnotetext{
${ }^{1}$ It is estimated that over 200,000 people in $\mathrm{BiH}$ work illegally.
} 
contribution rates, would be compensated through the introduction of people from the gray zone into the system. On the other hand, relieving the economy by reducing contributions, and introducing a stimulating tax rate on salaries ${ }^{2}$, would lead to new employment of unemployed persons, and the establishment of new legal entities, which directly stimulates economic activity. The introduction of people from the gray zone, as well as new employment, will lead to an increase in income, which will be spent, thus increasing the demand for goods and services. In that way, there is a direct growth of production, expansion of production capacities, and companies will decide to expand production or purchase some new machines, which also increases investment consumption. Every type of consumption is taxed through value added tax, which increases the collected indirect taxes, which make up the majority of total tax revenues, which is one of the goals of stabilizing public finances.

\section{CONCLUSIONS}

- Expansive fiscal policy in BiH during the period 2001-2008 led to a significant increase in GDP, which at the end of the period increased by $81.5 \%$ compared to the beginning.

- The policy of balanced budget in BiH during the period 2009-2020 led to limited and insufficient GDP growth in $\mathrm{BiH}$ in the amount of $32.7 \%$.

- Slower economic growth has led to a reduction in the labor force in $\mathrm{BiH}$ in the period 2014-2018 by 113,000 workers, emigration of 109,000 workers in the period 2014-2019, reduced levels of foreign direct investment and an increase in the gap with GDP pc compared to neighboring countries of the region.

- According to the regression analysis model, a simulation of government expenditures and the impact on GDP growth in the next four years was done. According to this model, a $10 \%$ increase in government expenditures per year will lead to a $31.9 \%$ increase in GDP.

\section{REFERENCES}

Agell, J., Lindh, T. and Ohlsson, H. (1997) "Growth and the public sector: A critical review essay”, European Journal of Political Economy, Vol. 13 No. 1, 33-52, available at: https://doi.org/10.1016/S0176-2680(96)00031-6

Barro, R. J. (1996). Determinants of Economic Growth: A Cross Country Empirical Study (1st ed.). The MIT Press.

Bosnjak, N. and Zlatkovic, M. (2015) "The Influence of Public Expenditures and Total-factor Productivity on the Economic Growth of Bosnia and Herzegovina" in Krstic, B. and Paszek, Z. (Eds), The Determinants of Competitiveness, pp.161-182.

DeLong, J. B. and Summers, LH. (2012) "Fiscal policy in a depressed economy", Brookings Papers on Economic Activity, 1, 233-297.

EUROSTAT, (2019a) "All valid permits by age, sex and citizenship on 31 December of each year", available at: https://ec.europa.eu/eurostat/databrowser/view/MIGR_RESVALID custom 591679/default/table?lang=en (Accessed 20 February 2021).

Fölster, S. and Henrekson, M. (1999) "Growth and the public sector: a critique of the critics", European Journal of Political Economy, Vol. 15 No. 2, 337-335, available at: https://doi.org/ $\underline{10.1016 / \mathrm{S} 0176-2680(99) 00010-5}$

Golemi, E. and Muço, K. (2020) "Fiscal policy's impact on economic growth-an estimation on eight Balkan countries", International Journal of Economic Policy in Emerging Economies, Vol. 13 No. 5, pp.514-525.

Hadzic, F., Imamovic, A. and Klepo, A., State Taxation System in Bosnia and Herzegovina and Redistribution of Resources. na.

\footnotetext{
${ }^{2}$ Salaries up to the amount of the consumer basket would be exempt from income tax.
} 
Hanusch, H., Chakraborty, L. and Khurana, S. (2017) "Fiscal policy, economic growth and innovation: An empirical analysis of G20 countries", Levy Economics Institute, Working Paper, (883).

Hodžić, S., Demirović, A. and Bečić, E. (2020) "The relathionship between fiscal policy and economic growth in CEE countries". In Proceedings of Rijek a Faculty of Economics: Journal of Economics and Business, Vol. 38, No. 2, pp. 653-666.

Jurić, T. and Hadžić, F., INSTITUT ZA MIGRACIJE I NARODNOSTI.

Turnovsky, S.J. and Wohar, M.E. (1987) "Alternative modes of deficit financing and endogneous monetary and fiscal policy in the USA 1923-1982", Journal of Applied Econometrics, Vol. 2 No. 1, pp.1-25.

Karalić, A. and Kumalić, J. (2020) "FISCAL AND TAX ADJUSTMENTS IN THE SERVICE OF ECONOMIC PROSPERITY OF BOSNIA AND HERZEGOVINA”, International Journal of Sales, Retailing \& Marketing, Vol. 9 No. 1.

Paparas, D., Richter, C. and Paparas, A. (2015) "Fiscal policy and economic growth, empirical evidence in European Union" Turkish Economic Review, Vol. 2 No. 4, pp.239-268.

Pasichnyi, M. (2017) "Empirical study of the fiscal policy impact on economic growth", Problems and perspectives in management, Vol. 15 No. 3, pp.316-322.

Shaw, C. (2016) Fiscal Policy and Economic Growth. Working paper.

Wildasin, D.E. (2000) "Factor mobility and fiscal policy in the EU: policy issues and analytical approaches”, Economic Policy, 15(31), pp.338-378. 